\title{
Positive Assessment: Iranian Pre-Intermediate EFL Learners' Speaking Skill and Their Self-Efficacy
}

\author{
Sahar Mihanyar ${ }^{1} \&$ Hamid Ashraf ${ }^{2 *}$
}

\author{
* Correspondence: \\ sahar.mihanyar@gmail.com \\ 1. Department of English, Tabaran \\ Institute of Higher Education, \\ Mashhad, Iran \\ 2. Department of English, Torbat-e \\ Heydarieh Branch, Islamic Azad \\ University, Torbat-e Heydarieh, Iran
}

Received: 9 September 2020

Revision: 24 November 2020

Accepted: 30 November 2020

Published online: 20 December 2020

\begin{abstract}
The current study was conducted to discover the impact of the positive assessment on Iranian pre-intermediate EFL learners' speaking skill and their self-efficacy. To accomplish the research, 40 Iranian females (17 to 8 years old) were selected from Shokooh Andishe Language Institute in Mashhad. A KET test which administered to determine the participants' level of proficiency. Then, they were divided into two groups, one control group and one experimental group (each included 20 participants). Two instruments, including KET speaking test and a self-efficacy questionnaire, were administrated to both groups as pre-tests. The experimental group received the treatment based on the principles of positive assessment i.e. using phrases such as very good, excellent, giving small gifts, using thrilling labels, and so forth. At the end of the study, the same instruments (as posttests) were conducted to collect the required data for the analysis. To measure the statistical differences between the means of two groups, some independent samples T-tests were calculated. The results of the analyses indicated that the experimental group outperformed the control group both in the case of speaking skill and self-efficacy. The findings of this research might be useful for EFL teachers and EFL learners, also they can be helpful for training programmers, institutes, and course designers.
\end{abstract} Keywords: EFL learners, positive assessment, $\underline{\text { self-efficacy, speaking skill }}$ 


\section{Introduction}

Today, students need new ways to progress in learning the language by which they reduce their stress in learning, while students are involved in oral communication. Based on my own experiences in teaching through assessment, teachers can understand what kind of procedure or technique could be appropriate to help students learn better and improve themselves in each skill that they need in the process of learning. In other words, assessment in a positive way causes students eagerly improve themselves. Another element which they need is self-efficacy. National Institute of Education (2014) believes assessment explores each pedagogical dimension in-depth and identifies the various elements and implementation strategies crucial for teachers' understanding of each. Teachers would discover evaluation useful to research some of these principles and strategies and reflect on their current teaching practices to bring suitable corrective change. NIE attempts to gather some of the common best teaching practices that are supported by researches. For instance, this training helps teachers to consider the best teaching programs and focus on appropriate assessment for learning, so that classroom instruction closely relates to that assessment. Teachers need to familiarize themselves to the forms of thinking, planning, delivering, and reflection that are emphasized on the appropriate assessment.

Mercer and Dawes (2014) offered some forms of assessment including: diagnostic assessment, formative assessment, summative assessment, norm-referenced assessment, criterion-referenced assessment, and interim or benchmark assessment. Diagnostic assessment evaluates a student's abilities, laxities, knowledge, and skills later to program. Formative assessment measures an individual implementation during instruction and often happens regularly via the instructional procedure. Summative assessment evaluates achievement of the learner at the finishing of instruction. Norm-referenced assessment compares the implementation of a learner in comparison with her or his classmates. Criterion-referenced assessment measures individual's performance opposite a goal, specific aim, or standard. Interim or benchmark assessment evaluates student's operation during terms, frequently at the end of a grading period. Those forms of assessment discussed above indicate that we do not take positive assessment into consideration as another type of assessment. Positive assessment means to assess students with using words such as good, very good, excellent, and well done. According to the data gathered from English language classrooms, Seedhouse (2004) claimed that positive evaluation is often implied in the absence of assessment in the initiation response assessment sequence (Sinclair \& Coulthard, 1975). There were a few number of research in this type of assessments, thus the results of this investigation could contribute scientific applications of positive assessment in pedagogy.

Communicating orally in English is still a big challenge for many students. To develop learners' oral proficiency and self-efficacy, positive assessment may provide young learners with opportunities to practice English in a meaningful context. But in order to increase self-efficacy while speaking, several obstacles such as stress, anxiety, self-confidence, and so forth needed to be overcome. Because teacher-centered classrooms still dominate, students are not accustomed to forming groups and completing tasks by themselves to increase their self-efficacy (Bandura, 2006a). Consequently, students easily go off task or have a disagreement with their group members, and preparing them to work well together consumes valuable class time so, a positive assessment may contribute to increasing the valuable class time by motivating students to use language and produce it orally.

Using positive assessment in evaluating learners in order to attract them toward the English course and increase their self-efficacy, also to employ language in speaking successfully, was a subject matter in pedagogy which few attentions were toward it. In a foreign language context, the development of learners' speaking skill may be particularly challenging. Learners in the class often have very different speaking abilities because exposure to an interaction in the second language (L2) outside the classroom tends to vary greatly, from extensive (travel, study, work abroad) to sporadic contact, if any at all. Learners may also have different learning goals and expectations that may affect their willingness to participate in oral activities. Furthermore, speaking is the one skill that involves a public display of abilities in the classroom, and anxiety has been presented to be more related to speaking than to any other skill (Horwitz \& Cope, 1986).

\subsection{Statement of the Problem}

For learning it is better to provide an enjoyable and effective setting to attract and develop learners' self-efficacy and abilities to have successful oral production. Using positive assessment was one of the important strategies of that learning situation since students endeavored to speak and getting positive words such as very good, excellent, well 
done and cool, so forth. Also, they were in good mood in such a situation and this procedure might contribute to reinforcing their self-efficacy.

Using positive assessment might not be very popular in many foreign language classes or maybe a few teachers have paid attention to the benefits it may have (Alibakhshi \& Sarani, 2014). Many teachers also might follow the typical strategies used by others and might not be aware of the probable effects of positive assessment on promoting the students' self-efficacy, and reducing their anxiety in oral communication (Kissling \& O'Donnell, 2015). Therefore, it showed that one of the important parts in making students' self-efficacy and producing language orally was not considered.

In responding to these problems, this study aims to investigate effect of the positive assessment on increasing selfefficacy and successful oral productions. Positive assessment as an approach may help students, when they feel peace in the class their brain reacts automatically toward each activity, then they participate in doing everything until they find themselves as a proficient person, this gives them and their teachers' proper energy to continue their effort.

\subsection{Research Questions and Null Hypotheses}

In order to investigate the effect of positive assessment on the Iranian pre-intermediate EFL learners' speaking skill and their self-efficacy, the following research questions were generated.

RQ 1. Does the application of positive assessment have any significant effects on the speaking skill of Iranian preintermediate EFL learners?

RQ 2. Does the application of positive assessment have any significant effects on self-efficacy of Iranian preintermediate EFL learners?

Based on the research questions, the following hypotheses were generated:

H0 1. Positive assessment does not have any significant effects on the speaking skill of Iranian pre-intermediate EFL learners.

H0 2. Positive assessment does not have any significant effects on self-efficacy of Iranian pre-intermediate EFL learners.

\section{Review of the Literature}

Positive evaluation is an analogy to Martin Seligman's PERMA framework (Seligman, 2012) from the region of wonderful psychology. PERMA describes five factors which might be critical for a satisfied, glad, and enjoyable life. The PERMA version is a nicely-being concept evolved by means of high-quality psychologist Martin Seligman. PERMA identifies 5 crucial factors of properly-being. By way of focusing on all 5 of those factors, people are able to flourish in lifestyles and discover the happiness we need. PERMA offers us the place to begin for dwelling some super lifestyles! Following the Seligman's view steered researchers to investigate the effect of fantastic evaluation on learners' speaking ability and their self-efficacy.

PERMA is an acronym for effective feelings, Engagement, (positive) Relationships, Means, and Accomplishment. Fine emotions are essential because now not experiencing negative feelings is not sufficient for being happy. Alternatively, people need to experience positive emotions including pleasure, contentment, or wish. Engagement Dr. Seligman refers to a sense of waft or general immersion in a challenge, which we are to revel infrequently, as an example of paintings or while exercising or playing a musical tool. Relationships or interactions with different people are critical for human properly-being, and it is far particularly critical to have deep and meaningful connections with others. Means refers to finding that means inside the things people do in their lives, for example at paintings or inside their families. Subsequently, accomplishments consult with the fact that people want to set themselves dreams, and that they sense happy while having reached them.

However, the teacher can assume positive evaluation may result in learning, but how this evaluation is provided its influence on learners and interplay to request a careful research that a corrective evaluation can play an important role in teacher learning (Voerman, Meijer, Korthagen, \& Simons, 2012; Wong \& Waring, 2009). In field of teaching, there were researches upon the effect of positive feedback on teaching speaking skill such as Muhsin. Muhsin (2016) 
claimed that positive assessment has a high effect on oral accuracy, but this influence is different for different level of learners.

Another article about positive assessment related to Harris (2016), he stated using positive assessment caused to motivate teachers in creating different classroom contexts also having cheerful and exhilarating class which make active students. Harris (2016) worked on the positive and negative assessment in language and other classes. He examined the nature and influence of positive assessment on class interplay. He said positive assessment is important in teacher learning, but there is little knowledge about how this form of evaluation can be carried out inside the teacher education class. He had three goals of this research: to discover the forms of positive evaluation and interactional contexts in which they are produced in the teacher education class. To consider the extent to which they lead to teacher learning. To notice to implications for teacher educator evaluation strategies regarding positive assessment. He provided four extracts in which they were done in interactional class based on the Task-based Learning and PERMA framework of Seligman, 2012 that was explained above. In extract one, he used teacher educator and learner teacher in class discussion then to note these results: the positive evaluations emerge in the third turn following teacher educator-learner teacher and are done by the teacher educator. To use word 'exactly' as positive assessment in this extract to be a teacher formulation and encourage learner teacher to act better. Extract two included teacher educator and two learner teachers. He received the same results as there were in first extract, but better because he used word 'good' when he assessed learners. In extract, three there were teacher educator, learner teacher, and sometimes learner teachers. Here, he applied word 'brilliant' in assessment that was played an important role in raising the production of right words quickly at the right time. He designed extract four with teacher educator and learner teacher this extract was the same extract one with the similar assessment (exactly), but different activity. He got the same results as extract one. In an instance of a teacher education class, the results demonstrated that positive assessment may not most of the time enlarge learning chances in interplay powerful contexts. In each class, positive evaluation is among the main factors influencing learning. He claimed it can be persuaded teachers to regard to this type of feedback, too.

Even though the students' errors are usual phenomena within the language classroom, it is miles pretty difficult to print out if the lecturers need to ignore or cope with them. If the lecturers determine to correct the mistakes, there must be as a minimum question to answer: which errors have to be corrected? And can the manner of instructors assist the scholars to make the mistakes work for them? The answers to those questions are as complicated as studying the language itself. It is important to note that there is a difference between assessment and feedback. Assessment refers to gathering information in order to make a decision about learning of the student; it means how the teacher can help the student to progress him or herself. But feedback is a way of providing data about learning of individual or acquiring skill in order to make a plan for the future learning goals and improving student's behavior and skill. However, feedback and assessment are close to each other in more of their goals. The language practitioners have had one of a kind reviews on how to deal with the scholars' mistakes. This assumption leads some scientists (Krashen, 1982; Truscott, 1996) keep in mind that the terrible comments make no sense in language classrooms.

Long (1996) has stated about negative and corrective assessment: negative points of assessment relate to the individuals that their utterances are defective in some way, and all assessments that are not negative, but to be positive. He additionally defies terrible feedback as giving a correction by using following an ungrammatical learner system. As an end result, pupil conversations often comprise long gaps of silence, short answers, and rigidly comply with question-answer patterns at the same time as motivation is significantly critical to the student gaining knowledge of, loss of motivation is a frequent problem with students in any respect degrees. All learning environments gift demanding situations, however the online. The environment offers particular demanding situations due to the fact that the students endure more obligation for their personal studying than in lots of traditional classes.

Furthermore, Alghazo, Abdurrahman, and Qbeitah (2009) have stated that error treatment does no longer enhance the scholars' oral skills. The opposing view, on the other hand, believed that error correction is essential in the language classroom because some researches have shown that if it is given in the proper way, it may enhance the students' language capabilities. Accordingly, Butler and Li (2001) have investigated the effectiveness of positive assessment among young EFL learners. They found some positive effects of positive assessment on the students' English performance as well as their confidence in learning English, though the effect sizes were small. Their study also found that teachers' and students' perceptions of the effectiveness of the positive assessment are different depending on their teaching/learning contexts. A number of interesting insights were also discovered through interviews with teachers. 
The teachers were asked about the best way to utilize self-assessment as a part of foreign language instruction in the contexts wherein teacher-centered teaching has been traditionally valued.

Many researchers have investigated the remarks of assessment in teaching. They did the research about the hard skills in English such as reading, writing, speaking, and listening. Pan (2015) has investigated the teacher assessment on the accuracy of English as a Foreign Language (EFL) student writing. He draws the conclusion in his study if teacher feedback has progressed the learners in better linguistic knowledge and it will ameliorate the accuracy of individuals in writing with a higher grade after receiving teacher's corrective feedback. As he asserted, positive feedback of teacher facilitated the capability of the student to write accurately.

Due to those demanding situations, college students' capability to persuade their own motivation is essential. Speakers of English must be capable of expressing themselves well and recognize the grammatical discourse, strategic, and sociolinguistic elements for any given situation based on a higher degree of communicative competence. In this example study, the researchers observed similar communicative development, however as her/his newbies are local they may have little trouble in expressing themselves nicely via the use of the English language (Namaziandost, \& Çakmak, 2020; Wolters \& Karabenick, 2005).

Here self-efficacy is based on the Bandura's studies between the years of 2001 to 2012. Self-efficacy can be invigorated by some things like positive feedback and push students to improve their performance in each part of their education (Bandura, 2012; Namaziandost, Hosseini, \& Utomo, 2020). Self-efficacy denotes people's beliefs about their potential to perform in different conditions. It functions as a multilevel and multifaceted set of ideas that influence how people sense, suppose, motivate themselves, and behave during diverse duties. Self-efficacy beliefs are informed by means of enactive attainment, vicarious experience, imaginal experiences, and social persuasion as well as bodily and emotional states. These ideas are mediated by cognitive, motivational, affective, and choice tactics to generate real overall performance. Self-efficacy improvement is closely intertwined with a person's stories, competencies, and developmental duties in exclusive domain names at different stages in lifestyles (Namaziandost, Pourhosein Gilakjani, \& Hidayatullah, 2020; Sandra \& Bella, 2011).

Studies along this line have shown that people's self-efficacy ideas about their abilities and the results of their efforts are especially predictive of real conduct, like academic overall performance and even vocational picks. Usher and Pajares (2008) believe that self-efficacy is also "related to key motivational constructs like causal attributions, selfidea, optimism, achievement goal orientation, academic help-looking for, tension, and value" (p.751) and is thus the maximum critical assembly of the social cognitive concept. In keeping with Klassen and Usher (2010), "Bandura's Social Cognition theory marks human functioning as manufactured from the dynamic interaction of private, behavioral, and environmental impacts. These factors exert their influence through a manner of reciprocal determinism, by way of which (a) personal elements within the shape of cognition have an effect on, and organize events, (b) conduct, and (c) environmental influences interact" (p. 3).

Every perception and its impact are sensitive to versions in situation, context, and venture, and that they orchestrate and steer someone's route of actions (overall performance) that generate consequences in the form of high quality or negative physical, social, and self-assessment results (Bandura, 1997; Namaziandost \& Ahmadi, 2019). Although numerous studies have dealt with assessment so far, rare studies, have been done in the context of Iran on the effects of positive assessment on Iranian pre-intermediate EFL learners' speaking skill and their self-efficacy. Therefore, this study aims to shed light on this important issue.

\section{Methodology}

\subsection{Design of the Study}

A quasi-experimental method of research was used in this study. Accordingly, the study employs a pre-test and posttest design to extract needed data of one experimental group (EG) and one control group (CG). This study focused on the variable of positive assessment as independent variable and speaking and self-efficacy as two dependent variables which are hypothesized to be affected by the independent variable. The collected data were analyzed quantitatively by using one-way Analysis of Covariance (ANCOVA) and paired samples t-test. 


\subsection{Participants and Setting}

The participants of this study were 40 Iranian EFL students from Mashhad, Iran. They were selected from among 90 students based on their performance in English language proficiency test of KET (The Key English Test developed by Cambridge exams). Their level was pre-intermediate. The participants of this study were selected from Shokooh Andishe Institute in Mashhad. They were all female and their age ranges between 17 to 18 years old. They were randomly divided into two groups; one experimental $(n=20)$ and one control $(n=20)$.

\subsection{Instruments}

To collect the required data, two instruments were used: a speaking KET test and students' Self-Efficacy questionnaire.

\subsubsection{KET Speaking Test}

KET speaking test (The Key English Test) which is the easiest type of the Cambridge exams and appropriate for preintermediate level includes different sections. Part one contains a group of questions that examiner asks and examinee responds. Part two requires the participants to tell stories. Part three includes telling differences of persons, shapes, and so forth. Part four contained a conversation. Part five contained a lecture, in this part the examiner used a few photos and asked the participants to speak about those pictures. In order to control the reliability of the test, the speaking test was recorded so that it could be used by two other raters. The inter-rater reliability measured through Kappa is indicated in Table 1. It should be mentioned that the score of the test ranged from 3 to 10.

Table 1. Results of Cohen's Kappa

\begin{tabular}{llcccc}
\hline & Value & $\begin{array}{c}\text { Asymp. Std. } \\
\text { Error }^{\mathrm{a}}\end{array}$ & Approx. T & Approx. Sig. \\
\hline Measure of Agreement & $\begin{array}{l}\text { Kappa } \\
\text { N of Valid Cases }\end{array}$ & .828 & .06 & 14.00 & .000 \\
\hline
\end{tabular}

a. Not assuming the null hypothesis.

b. Using the asymptotic standard error assuming the null hypothesis.

The result of the inter-rater analysis indicates Kappa $=0.828$ with $\mathrm{p}<0.000$. This measure of agreement, while statistically significant, is only marginally convincing. As a rule of thumb, values of Kappa from 0.40 to 0.59 are considered moderate, 0.60 to 0.79 substantial, and 0.80 outstanding (Landis \& Koch, 1977). Most statisticians prefer for Kappa values to be at least 0.6 and most often higher than 0.7 before claiming a good level of agreement.

\subsubsection{Self-efficacy Questionnaire}

To measure the students' self-efficacy, the questionnaire which was modified in Iran by Khamesan and Ramazani (2010) was implemented. The original questionnaire was developed by Zimmerman and Kitsantas (2005). It included 57 questions and 5 components: reading, note taking, test taking, writing, and studying, but the components reading and test taking (containing 22 questions) were used in this research. The reported reliability for the whole questionnaire is 0.89 , and for the components of reading and test taking were 0.79 and 0.70 respectively. To make sure the instrument possesses the appropriate reliability index, the present study data were analyzed through Cronbach Alpha formula. The result showed that the Cronbach Alpha was 0.975.

\subsection{Data Collection Procedure}

Through two pre-tests, a speaking KET test and a Self-efficacy questionnaire, the researchers made sure that both groups did not have any significant differences in their language proficiency, speaking skill, and self-efficacy. The participants in the experimental group received positive assessment. The treatment lasted for two terms. They received wonderful factors when they guessed the meaning of words, did more workout automatically, guessed synonym or 
antonym of words, drew pictures on the board or did role play, and used gesture to guess. They got positive points and words when they summarized the stories of their book without mistakes and fluent. They obtained labels (fancy tags) after they got three points. If their midterm scores were above 36, they received small gifts. The teacher sent assessed exam papers to the students' parents and explained their function and progress. Also, if they could improve their scores and behavior remarkably, they got one of these positive assessment things that were mentioned above. As the experimental group was undertaking this research, the control group did not receive any kind of those positive assessments and they passed their terms in the normal educational program.

\subsection{Data Analysis}

After gathering the needed data through the aforesaid procedures, the data were analyzed and interpreted according to the objectives of the study. The data were analyzed with the help of Statistical Package for Social Science (SPSS) software. In order to check the normality of the data, Kolmogorov-Smirnov (K-S) test was used. Then, paired samples t-test and one-way ANCOVA were applied to measure the effectiveness of the treatment on improving the students'" speaking and self-efficacy.

\section{Results}

Before doing any analysis, it was necessary to check the normality distribution of the data. After running the OneSample Kolmogorov-Smirnov test, it was revealed that the statistics of scores were normal since the p-values were greater than .05. Therefore, it was safe to run parametric statistics.

\subsection{Results of Post-Test (Speaking Skill)}

As the first research question of the study was intended to figure out whether the application of positive assessment has any significant effects on the speaking skill of Iranian pre-intermediate EFL learners, the post-test scores of the EG and CG learners had to be compared. To attain this objective, the researchers could run an independent-samples $t$ test, but to control for any possible pre-existing differences between these two subgroups, and compare their post-test scores accordingly, one-way ANCOVA was chosen to be conducted. The results obtained from this statistical test are presented in Tables 2 and 3.

Table 2. Descriptive statistics for post-test results on speaking skill test of both groups

\begin{tabular}{lccccccr}
\hline \multicolumn{1}{c}{ Groups } & Mean & Std. Deviation & $\mathrm{N}$ & \multicolumn{2}{c}{ Skewness } & \multicolumn{2}{c}{ Kurtosis } \\
\hline & & & & Statistic & Std. Error & Statistic & Std. Error \\
\hline Experimental & 7.45 & .68 & 20 & -.07 & .51 & .54 & .99 \\
\hline Control & 5.62 & 1.15 & 20 & -.76 & .51 & .02 & .99 \\
\hline Total & 6.53 & 1.31 & 40 & -.07 & .51 & .54 & .99 \\
\hline
\end{tabular}

Based on the data indicated in Table 2, the means of the experimental group and the control group are 7.45 and 5.62, respectively. 
Table 3. Results of One-Way ANCOVA for comparing the post-test scores of EG and CG on speaking skill test

\begin{tabular}{lrrrrrr}
\hline Source & $\begin{array}{c}\text { Type III Sum } \\
\text { of Squares }\end{array}$ & df & Mean Square & F & Sig. & $\begin{array}{c}\text { Partial Eta } \\
\text { Squared }\end{array}$ \\
\hline $\begin{array}{l}\text { Corrected } \\
\text { Model }\end{array}$ & 44.06 & 2 & 22.03 & 34.488 & .000 & .65 \\
\hline Intercept & 28.40 & 1 & 28.40 & 44.47 & .00 & .54 \\
\hline $\begin{array}{l}\text { Pretest of } \\
\text { Speaking }\end{array}$ & 10.75 & 1 & 10.75 & 16.83 & .00 & .31 \\
\hline Groups & 34.89 & 1 & 34.89 & 54.62 & .00 & .59 \\
\hline Error & 23.63 & 37 & .63 & & & \\
\hline Total & 1777.25 & 40 & & & & \\
\hline Corrected Total & 67.69 & 39 & & & & \\
\hline
\end{tabular}

In Table 3, if you find the row labeled Groups in the leftmost column, and read across this row, under the Sig. column, you can find the $\mathrm{p}$ value, which should be compared with the alpha level of significance (i.e., .05). The $\mathrm{p}$ value here was lower than the alpha level of significance $(.00<.05)$, which indicates that the difference between the two groups of EG and CG on the speaking post-test was statistically significant. This means that using the positive assessment could significantly improve the speaking skill of the EG learners.

Another noteworthy piece of information in Table 3 is the effect size value, shown under the Partial Eta Squared column in front of Groups. This value equaled .59, which means that the treatment (i.e., using positive assessment) accounted for 59\% of the difference between the EG and CG learners. Thus, the first hypothesis stating that positive assessment does not have any significant effects on the speaking skill of Iranian pre-intermediate EFL learners was rejected. The results indicate that the participants in the experimental group outperformed those in the control group in their speaking skill.

\subsection{Results of Post-Test (Self-efficacy)}

The second research question of the study was essentially similar to the first one, except that it was self-efficacy of the EFL learners. That is, it intended to find out whether the application of positive assessment has any significant effects on self-efficacy of Iranian pre-intermediate EFL learners. Thus, the self-efficacy post-test scores of the EG and CG learners were compared through a one-way ANCOVA. The results obtained from this statistical test are presented in Tables 4 and 5.

Table 4. Descriptive statistics for post-test results on self-efficacy test of both groups

\begin{tabular}{cccccccc}
\hline Groups & Mean & Std. Deviation & N & \multicolumn{2}{c}{ Skewness } & \multicolumn{2}{c}{ Kurtosis } \\
\hline & & & & Statistic & Std. Error & Statistic & Std. Error \\
\hline Experimental & 80.35 & 4.45 & 20 & .76 & .51 & -.23 & .99 \\
\hline Control & 69.45 & 15.08 & 20 & 1.20 & .51 & .86 & .99 \\
\hline Total & 74.90 & 12.28 & 40 & .76 & .51 & -.23 & .99 \\
\hline
\end{tabular}

The data shown in Table 4 indicates that the means of the experimental group and the control group are 80.35 and 69.45 , respectively. 
Table 5. Results of One-Way ANCOVA for comparing the post-test scores of EG and CG on self-efficacy test

\begin{tabular}{lrrrrrr}
\hline Source & $\begin{array}{c}\text { Type III Sum } \\
\text { of Squares }\end{array}$ & df & Mean Square & F & Sig. & $\begin{array}{c}\text { Partial Eta } \\
\text { Squared }\end{array}$ \\
\hline $\begin{array}{l}\text { Corrected } \\
\text { Model }\end{array}$ & 1875.42 & 2 & 937.71 & 8.64 & .00 & .31 \\
\hline Intercept & 8465.64 & 1 & 8465.64 & 78.03 & .00 & .67 \\
\hline $\begin{array}{l}\text { Pretest of Self- } \\
\text { efficacy }\end{array}$ & 687.32 & 1 & 687.32 & 6.33 & .01 & .14 \\
\hline Groups & 1551.63 & 1 & 1551.63 & 14.30 & .00 & .27 \\
\hline Error & 4014.17 & 37 & 108.49 & & & \\
\hline Total & 230290.00 & 40 & & & & \\
\hline Corrected Total & 5889.60 & 39 & & & & \\
\hline
\end{tabular}

The $p$ value under the Sig. column in Table 5 was smaller than the alpha level of significance $(.00<.05)$, indicating that the difference between the two groups of EG and CG on the self-efficacy post-test reached statistical significance. Accordingly, using the positive assessment could significantly improve the self-efficacy of the EG learners. It is also worth noting that the effect size value, shown under the Partial Eta Squared column in front of Groups, equaled .62, which means that the treatment (i.e., using the positive assessment) accounted for $27 \%$ of the difference between the post-test self-efficacy scores of the EG and CG learners. Thus, the second hypothesis stating that positive assessment does not have any significant effects on the self-efficacy of Iranian pre-intermediate EFL learners was rejected. Lastly, to check the performance of each group from pre-test to post-test on both speaking and self-efficacy tests, a paired samples t-test was run.

Table 6. Paired samples test comparing the performance of both groups from pre-test to post-test on both speaking and self-efficacy tests

\begin{tabular}{|c|c|c|c|c|c|c|c|}
\hline & & Mean & $\begin{array}{c}\text { Std. } \\
\text { Deviation }\end{array}$ & $\begin{array}{l}\text { Std. Error } \\
\text { Mean }\end{array}$ & $\mathrm{t}$ & $\mathrm{df}$ & $\begin{array}{l}\text { Sig. }(2- \\
\text { tailed) }\end{array}$ \\
\hline $\begin{array}{l}\text { Pair } \\
1\end{array}$ & $\begin{array}{l}\text { EG. Speaking Post - EG. } \\
\text { Speaking PRE }\end{array}$ & 2.00 & .97 & .21 & 9.18 & 19 & .00 \\
\hline $\begin{array}{l}\text { Pair } \\
2\end{array}$ & $\begin{array}{l}\text { CG. Speaking Post }- \text { CG. } \\
\text { Speaking Pre }\end{array}$ & .07 & 1.07 & .24 & .31 & 19 & .75 \\
\hline $\begin{array}{l}\text { Pair } \\
3\end{array}$ & $\begin{array}{l}\text { EG. Self-efficacy Post - EG. } \\
\text { self-efficacy Pre }\end{array}$ & 19.90 & 16.81 & 3.76 & 5.29 & 19 & .00 \\
\hline $\begin{array}{l}\text { Pair } \\
4\end{array}$ & $\begin{array}{l}\text { CG. Self-efficacy Post-CG. } \\
\text { self-efficacy Pre }\end{array}$ & 1.60 & 15.65 & 3.50 & .45 & 19 & .65 \\
\hline
\end{tabular}

As can be seen in Table 6, the experimental group in both speaking and self-efficacy tests improved from pre-test to post-test ( $\mathrm{p}$ value $<.05$ ) but no change was found in the control group performance from pre-test to post-test on both speaking and self-efficacy tests ( $\mathrm{p}$ value $>.05)$.

\section{Discussion}

The present study tested the hypotheses that positive assessment does not have any significant effects on the speaking skill and self-efficacy of Iranian pre-intermediate EFL learners. In doing so, participants in experimental group received a 10-session treatment in which they received positive assessment. After analyzing the data, it was revealed that there was a significant difference between the mean scores of the pre-intermediate EFL learners in both speaking fluency and accuracy posttests. The mean of the experimental group was significantly higher than the mean scores of the control group. Therefore, it could be strongly argued that positive assessment had a significant impact on pre- 
intermediate learners' speaking skill and self-efficacy. The results of the current study are supported by Butler and Li (2005) who investigated the effectiveness of positive assessment among young EFL learners and found some positive effects on the students' English performance as well as their confidence in learning English. Moreover, in line with a few recent studies (Alibakhshi \& Sarani, 2014; Pellegrino \& Chudowsky, \& Aglaser, 2001) it could be argued that positive assessment has a significant positive effect on students' learning.

Therefore, the process of the positive assessment, which included in this study, indicates that when students are given positive reactions, they were able to perform better in their speaking test. It is a process through which they find out about their learning. The process involves them in recognizing, evaluating, and reacting to their own learning outcome. Students did reflect on their own performance, as well as they have received constructive positive feedback from their teacher. Positive assessment outcome in this study is also an indication of the importance of proper feedback to students in which teachers find out about the effectiveness of the learning process. Accordingly, Chickering and Gamson (1991) claim that frequent feedback as a result of assessments can keep students on task by helping to identify areas in which the student is not performing well. It can be viewed as the process by which teachers gather assessment information about the students' learning and then respond to promote further learning and better performance. For example, assessment should contribute to instructions and learning. However, assessment after the instructions are over, does not allow the assessment to contribute to any instructional decisions. This can conclude to what extent students master some amount of content. Thus, assessment must be a continuous process that facilitates "on-line" instructional decision-making in the classroom (Gitomer \& Duschl, 1995, p.307).

Previous studies explained similar variables in the fields of teaching and psychology. More researches in the area of self-efficacy were done by Bandura (2012). He asserted that self-efficacy can be nourished through some things such as positive assessment to move learners toward improving their performance in each part of their learning and life. In the field of teaching there were many studies about effects of corrective assessment on teaching learning skills as Muhsin (2016) explained positive feedback can have a great influence on speaking skill, but this effect is not the same for all levels of individuals. Another point of view is related to Harris (2016), claiming using positive evaluation can be caused to push and motivate educators in creating different situations in the class based on the ability and understanding of learners to bring happiness to the class which makes energetic individuals.

To compare the findings of this study with other researches in the part of teaching different kinds of skills specially, speaking skill, Muhsin (2016) explained the most universal positive feedback in teaching speaking is the explicit correction, elicitation, and repetition. Positive assessments have an influential function in finding the wrong pronunciation of individuals and also their low accuracy and fluency. Other positive feedback like implicit correction, recast, specification request, and metalinguistic feedback are not considered. Because the percent of it is lower than other positive feedback, so it could be understood not all positive feedback is impressive if used in oral skill, relate to that skill. One of the major problems in English classes is the fact that most of the students are not participating in the different class discussions and they are stressful and anxious to start to speak, therefore most of the class time is devoted to more proficient students. Positive assessment might have been one of the solutions to the mentioned problem.

Based on point of view asserted by Chu (2011), positive feedback has positive influence on improving oral skill accuracy. Relying on opinion was expressed if there were no enough levels of self-efficacy willfulness, behavioral change may not be possible (Bandura, 2006). Teachers should be aware of these important issues in order to improve their teaching so paying attention to these matters can greatly increase their work efficiency which directly influences the learning of students. Also, training programmers, educational policymakers, institutes, and course designers should consider the findings of this research and employ some principles to ameliorate English language teaching and learning process. As well as findings can help students to know whether their teachers are up to date or not. The results of the study indicated that experimental group, which received instruction in the use of positive assessment, outperformed the control group, suggesting that the positive assessment improves learners' speaking skills and self-efficacy. In other words, positive assessment helps the learners to feel more confident expressing themselves and managing stressful situation that might be caused due to their language deficiencies.

\section{Conclusion}

This research was intended to investigate the effect of positive assessment on Iranian pre-intermediate EFL learners' speaking skill and their self-efficacy. By relying on findings of this study, positive assessment in measuring speaking 
skill and self-efficacy of learners should be taken into consideration as important and useful factor in every English class. The findings of this paper have important implications for many teachers related and interested in EFL field. This research identified the effect of a new way in EFL, the evidences of this paper will be useful especially for those teachers tend to have successful classes and enjoy their classes, also for those who try to avoid the traditional ways and approaches. Also, it can be helpful for training programmers that change their intuition in providing English book and for institute if they tend to have English learners with high proficiency in their speaking with the best self-efficacy. However, the findings revealed that positive assessment can develop other skills in training individuals. The participants of this study were mainly included in one private language institute and they were just females. More specific results and conclusions can be obtained if participants of future research into this subject to be chosen without the limitations of their numbers and gender. This paper just examined the effect of the positive assessment of Iranian pre-intermediate EFL learners' speaking skill and their self-efficacy, the future research related to this matter can add and measure the effect of other variables to this effect like other aspects of assessment and other skills such as writing, reading, listening, and also sub-skills like vocabulary and grammar. This part of work was mainly contributed to the EFL field, but future studies can be done in a related field like English as a Second Language (ESL).

\section{References}

Alghazo, K., Abdelrahman, M. B., \& Qbeitah, A. A. (2009). The effect of teachers' error feedback on Al-Hussein Bin Talal university students' self-correction ability. European Journal of Social Sciences, 12(1), 146-160. https://www.researchgate.net/publication/242699415 The_Effect_of_Teachers\%27_Error_Feedback_on_Al -Hussein_Bin_Talal_University_Students\%27_Self_Correction_Ability

Alibakhshi, G., \& Sarani, A. (2014). Self-assessment impact on EFL learners' speaking fluency and accuracy: Does level of proficiency matter? TELL, 8(2), 119-143. https://www.sid.ir/en/Journal/ViewPaper.aspx?ID=599687

Bandura, A. (1997). Self-efficacy: the exercise of control. New York: Freeman.

Bandura, A. (2006a). Toward a psychology of human agency. Perspectives on Psychological Science, 1(2), 164-180. https://doi.org/10.1111/j.1745-6916.2006.00011.x

Bandura, A. (2012). On the functional properties of perceived self-efficacy revisited. Journal of Management, 38(1), 9-44. https://doi.org/10.1177/0149206311410606

Chickering, A., \& Gamson, Z. (Eds.). (1991). Applying the seven principles for good practice in undergraduate education. San Francisco: Jossey-Bass.

Chu, R. (2011). Effects of teacher's corrective feedback on accuracy in the oral English of English-majors college students. Theory and Practice in Language Studies, 1(5), 454-459. doi:10.4304/tpls.1.5.454-459

Gitomer, D., \& Duschl, R. (1998). Emerging issues and practices in science assessment. In B. Fraser\& K. Tobin (Eds.), International handbook of science education. Dordrecht: Kluwer Academic Publishers.

Harris, S. (2016). Positive assessments in teacher learning. ELT Journal, 71(2), 1-25. doi: 10.1093/elt/ccw066

Horwitz, E., Horwitz, M., \& Cope, J. (1986). Foreign language classroom anxiety. Modern Language Journal, 70(2), 125-132. https://doi.org/10.2307/327317

Khamesan, A., \& Ramazani, Z. (2010). A pattern to predict academic cheating: The role of achievement goals, selfefficacy, and academic involvement among the Payame-Noor students in Esfarayen City during 2009-2010. The Persian Archives of Birjand University.

Kissling, E. M., \& O’Donnell, M. E. (2015). Increasing language awareness and self-efficacy of FL students using self-assessment and the ACTFL proficiency guidelines. Language Awareness, 24(4), 283-302. doi: $\underline{10.1080 / 09658416.2015 .1099659}$

Klassen, R. M., \& Usher, E. L. (2010). Self-efficacy in educational settings: Recent research and emerging directions. Advances in motivation and achievement, 16, 1-33. doi: 10.1108/S0749-7423(2010)000016A004

Krashen, S. (1982). Principles and practice in second language acquisition. Oxford: Pergamon. 
Long, M. H. (1996). The role of the linguistic environment in second language acquisition. In W. C. Ritchie, \& T. K. Bhatia (Eds.), Handbook of second language acquisition (pp. 413-468). New York: Academic Press.

Mercer, N., \& Dawes, L. (2014). The study of talk between teachers and students from the 1970s to the2010s. Oxford Review of Education, 40(4), 430-445. https://doi.org/10.1080/03054985.2014.934087

Muhsin, M. A. (2016). The effectiveness of positive feedback in teaching speaking skill. Lingua Cultural, 10(1), 2530. http://dx.doi.org/10.21512/lc.v10i1.873

Namaziandost, E., \& Ahmadi, S. (2019). The assessment of oral proficiency through holistic and analytic techniques of scoring: A comparative study. Applied Linguistics Research Journal, 3(2), 70-82. doi: 10.14744/alrj.2019.83792

Namaziandost, E., \& Çakmak, F. (2020). An account of EFL learners' self-efficacy and gender in the flipped classroom model. Education and Information Technologies, 25(2). https://doi.org/10.1007/s10639-020$\underline{10167-7}$

Namaziandost, E., Hosseini, E., \& Utomo, D. W. (2020). A comparative effect of high involvement load versus lack of involvement load on vocabulary learning among Iranian sophomore EFL learners. Cogent Arts and Humanities, 7(1). https://doi.org/10.1080/23311983.2020.1715525

Namaziandost, E., Pourhosein Gilakjani, A., \& Hidayatullah. (2020). Enhancing pre-intermediate EFL learners' reading comprehension through the use of Jigsaw technique. Cogent Arts \& Humanities, 7(1), 1-15. https://www.tandfonline.com/doi/full/10.1080/23311983.2020.1738833

Pan, Y. (2010). The effect of teacher error feedback on the accuracy of EFL student writing. TEFLIN Journal, 21(1), 57-77.

Pellegrino, J. W., Schakowsky, N., \& Aglaser, R. (2001). Knowing what students know: The science and design of educational assessment. Washington, DC: National Academic Press.

Sandra, K., Tsang, M., Bella C., \& Law, M. (2011). Self-efficacy as a positive youth development construct: A Conceptual Review. The Scientific World Journal, 1-7. doi:10.1100/2012/452327

Seedhouse, P. (2004). The interactional architecture of the language classroom: A conversation analysis perspective. Malden, MA: Blackwell Publishing, Inc.

Seligman, M. (2012). Flourish: A visionary new understanding of happiness and well-being by Martin E.P. Seligman - A Book Review. NHRD Network Journal, 9(4), 106-109. doi: 10.1177/0974173920160420

Sinclair, J. M., \& Coulthard, M. (1975). Towards an analysis of discourse: The English used by teachers and pupils. London: Oxford University Pressing.

Truscott, J. (1996). The case against grammar correction in L2 writing classes. Language Learning, 46(2), 327-369. https://doi.org/10.1111/j.1467-1770.1996.tb01238.x

Usher E. L., \& Pajares, F. (2008). Sources of self-efficacy in school: a critical review of the literature and future directions. Review of Educational Research, 78(4), 751-796. doi: 10.3102/0034654308321456

Voerman, L., Meijer, P., Korthagen, F., \& Simons, R. (2012). Types and frequencies of feedback interventions in classroom interaction in secondary education. Teaching and Teacher Education, 28(8), 1107-1125. https://doi.org/10.1016/j.tate.2012.06.006

Wolters, C. A., Pintrich, P. R., \& Karabenick, S. A. (2005). Assessing academic self-regulated learning. In K. A. Moore \& L. H. Lippman (Eds.), The search institute series on developmentally attentive community and society. What do children need to flourish: Conceptualizing and measuring indicators of positive development (p. 251-270). Springer Science + Business Media.

Wong, J., \& Waring, Z. (2009). Very good as a teacher response. ELT Journal, 63(3), $195-203$. https://doi.org/10.1093/elt/ccn042 
Zimmerman, B. J., \& Kitsantas, A. (2005). The hidden dimension of personal competence: Self-regulated learning and practice. In A. J. Elliot \& C. S. Dweck (Eds.), Handbook of competence and motivation (p. 509-526). Guilford Publications. https://psycnet.apa.org/record/2005-08058-027 